\title{
МИтРА М. РЕљИЋ ${ }^{1}$
}

УНИВЕРЗИТЕТ У ПРИШТИНИ СА ПРИВРЕМЕНИМ СЕДИШТЕМ

У КОСОВСКОЈ МИТРОВИЦИ, ФИЛОЗОФСКИ ФАКУЛТЕТ,

КАТЕДРА ЗА РУСКИ ЈЕЗИК И КЬИЖЕВНОСТ

\section{ПОЈАМ СЛАВЕ У КЮИЖЕВНОМ И ПУБЛИЦИСТИЧКОМ СТВАРАЛАШТВУ ТОКОМ ВЕЛИКОГ РАТА}

САЖЕТАК. Слава је један од чешћих појмова међу онима који се срећу на страницама литерарних и других сведочења настајалих на фронту и у позадини Великог рата 1914-1918. Његова концептуална структура, предочена у поменутом стваралаштву и периоду, осим општесловенских значења славе, изнова потврђује и нека, само српској култури својствена значења. Анализом текстова дошло се до закључка да је из комплекса речницима фиксираних (или изостављених) значења, за концепт славе у годинама Великог рата типична: 1) војничка, херојска слава, 2) крсна слава, и 3) Слава Божија, те да иста значења доминирају и код данашњих корисника српског језика.

КљУЧНЕ РЕЧИ: Велики рат, слава, концепт, концептуална метафора, језичка слика света.

1 hvostanskazemlja@gmail.com

Рад је настао у оквиру ангажовања на пројекту Ойис и сйанgарgизаиија савременої срйскої језика (178021), који финансира Министарство просвете и науке Републике Србије и прочитан је на Међународном научном скупу „Велики рат 1914-1918: узроци, последице, тумачења“, одржаном у Врању 3. и 4. октобра 2014.

Рад је примљен 12. априла 2017, а прихваћен за објављивање на састанку Редакције 3борника одржаном 22. јуна 2017. 
Подсећајући како су у годинама Великог рата поједини наши културни делатници у Паризу и другим центрима жудели за поетским вербализмом и лажном патетиком „са којом би изашли не пред Милоша него пред монденску Европу“, Станислав Винавер у наставку пише:

„Њима је требало славе и блеска за извоз, и они нису били свесни тога да смо ми имали праве славе, за хиљаду година и за сто хиљада година, као радијума, који заиста сам по себи зрачи, и да нам не треба мешане славе и у другим облицима, кад је већ имамо у чистоме виду [...] Наша је слава сама по себи била јасна, и она ће блистати вечито, а да се не јави потреба ни једне литерарне речи, ни једног литерарног папирног венца око њеног пламена. И изгорео ठи тај венац...“ (Винавер, 1971, стр. 294-295).

Предмет овог рада јесте управо концепт славе, као динамичког вербалног конструкта (културног отиска) у човековој менталној свести, представљеног у поетским и прозним - књижевним, публицистичким, дневничким и другим записима настајалим у периоду Великог рата. Циљ рада је да се дата представа упореди са оном у језичкој слици света данашњих корисника српског језика - с једне стране, и у речницима фиксираним значењима лексеме слава - с друге стране.

Емпиријску подлогу истраживања представља грађа ексцерпирана из новинских и различитих других ратних и поратних издања, у првом реду Крфскої забавника као додатка ондашњих

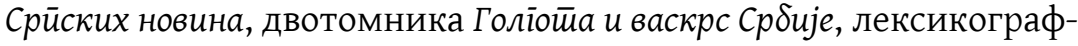
ски подаци те резултати у новије време спроведене анкете.

Етимолошки корени општесловенске речи слава, као и њој обликом и значењем сродних šlóvé, šlãvé и др. у литванским гово-

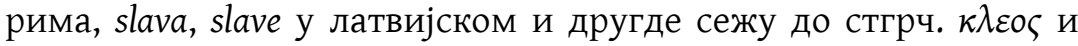
стинд. crávas те авест. sravah- (в. Фасмер, 1987). Према мишљењу Александра Ломе „Словенски облик *slava је или образован директно од *slovo каo vrrddhi - изведеница са дужењем коренског вокала о̌ > a, или се ради о поствербалу од глагола *laviti, који је, са своје стране, итератив од sloviti, а овај деноминатив од slovo“ (2002, стр. 171). Ова, као и многе друге речи, у процесу историјског развоја језика̄, мењала је своја статусна и значењска обележja, при чему је аксиолошка компонента представљала константу њоме исказаног појма. Иако се у свакодневном говору данашњих корисника словенских језика, као и у појединим речницима, нпр. Фасмеровом Ейимолошком речнику рускої језика, реч слава јавља као синоним речи час $\bar{u}$, Ј. Лотман (1992, стр. 111-126) је јасно 
показао да у средњовековном феудалном друштву међу двама појмовима постоји битна разлика. ${ }^{2}$ Мада једно и друго има статус знака, „Појам славе је - напомиње Лотман - у знатно већем степену семиотичан“. С обзиром на то да је у периоду средњовековља лишена сваког материјалног предзнака „славу је могуће наследити од потомака, далеких народа, купити је ценом смрти [...] Слава је индиферентна у односу на резултате - њу феудалац може стећи и у победи и у поразу, уколико притом досегне највише норме витештва“ (Лотман, 1992, стр. 115). Анализом каснијих књижевних текстова Лотман долази до закључка да

„У рационалистичкој култури класицизма част постаје једна од основних одредница сталешког племићког морала [...] Притом, управо части се приписивала знаковна изванпрактична вредност [...] и у вези са тим у систему руског класицизма XVIII в. 'част' се поима као нешто више него 'слава'. Истовремено се дешава брисање разлике међу тим појмовима, те се они све чешће јављају као међусобно заменљиви (или скоро међусобно заменљиви) синоними“,

да би се у ери просветитељства према датим, као и другим чисто знаковним појмовима, као фикцијама феудалног друштва, развио веома негативан однос (стр. 119). И данас се, нажалост, само са нешто другачијим мотивима, слава неретко представља као фикција, и то у првом реду војничка, херојска слава, и пре свега она која је обележила историју властитог (српског) народа. Ста-

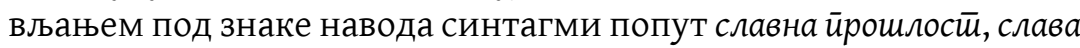
ūpegaкa и др., метафоризацијом, оказионализацијом и на друге начине, у дискурсу немалог броја корисника српског језика тежи се ресемантизацији и релативизацији не само датог појма већ и читавих, несумњиво славних периода српске историје, укључу-

2 Та разлика је евидентна и данас. Синонимичност двају појмова искључују, између осталог, бројне синтагматске везе са речју слава: йронейи славу, нейролазна слава, сйара слава, йрошла слава, сјај славе и немогуће везе: *йронейи

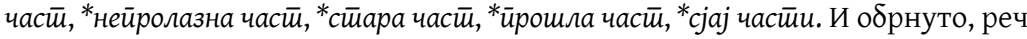

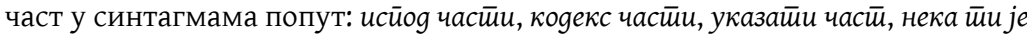

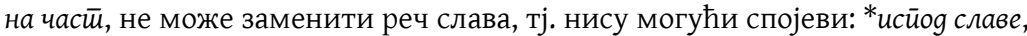

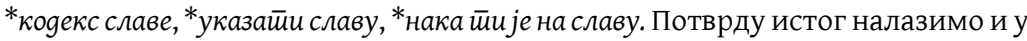
Асоиијайивном речнику срӣскої језика (Пипер и др. 2005, стр. 517) из којег се види да је на реч часй од 800 испитаника само њих 8 реаговало речју слава. М. Рамшак (2013, стр. 10) примећује да је слава, као један од појмова који се у свакодневном језику мешају са појмом часйи, заправо последица части, те да се „За разлику од части, слава [се] односи само на вањску част коју исказује заједница, док је част индивидуални осјећај властите вриједности који је поткријепљен врлином и прије но што дође до јавног признања“ (стр. 21). 
јући и Велики рат 1914-1918. Тако се један социолог постмодернистичке оријентације и професор универзитета „прославио“ кованицом солунашйво коју у својству негативне метафоре премешта из текста у текст, с намером да доведе у питање херојски и етички карактер поменутог периода. Међутим, свакојаки покушаји да се српско жртвовање за слободу обеслави те, у складу са савременим друштвеним кретањима, прво место на скали значења обезбеди слави која имплицира јевтину популарност, новац и моћ, као што ћемо видети, нису уродили плодом.

Лексему слава карактерише висока творбена продуктивност

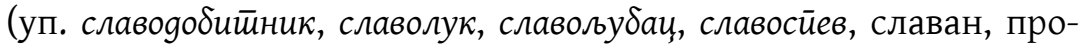
славити, славословит̄и итд.), а о њеном присуству и значају у српској лингвокултури казује чињеница да она представља једну од најфреквентнијих основа српских имена и презимена (Лазаревић, 2001). У лексикографској одредници шестотомног Речника

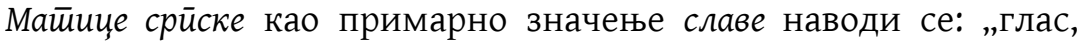
углед, надалеко познат као сведочанство општег признања за заслуге, за јунаштво, успех у чему и сл.“, на другом месту је „јавно мишљење о нечијим врлинама и недостацима“, на трећем „рад, поступак који заслужује поштовање, заслуга“, на четвртом стоји „хвала, захвалност“ и тек на петом - „крсно име“, односно „црквени празник“. Тако би требало да гласи представа славе у језичкој слици света данашњих корисника српског језика, с обзиром на то да је једна од важних функција речника пружање такве врсте информација. А да ли је баш тако и у којој се мери тај концепт подудара са стварном представом славе у свести савремених носилаца српског језика, а у којој се разликује од оне из времена Великог рата од пре сто година? Подсећајући на објективне тешкоће са којима се сусрећу лексиколози и лексикографи при утврђивању примарног значења вишезначних лексема, Р. Драгићевић констатује да при изради описних речника не треба заобилазити језичко осећање говорних представника, које успешно презентују њихове вербалне асоцијације (2010, стр. 63-67).

„Концептуално поље речи 'слава' - напомиње Ј. Нагибина - има сложену структуру коју је могуће представити у виду парадигми које експлицирају његове смисаоне секторе“ (Нагибина, 2002). Приметно је да из низа парадигми: слава - част; слава - узвишеност; слава - благодарност; слава - похвала (хвалоспев); слава - раскош; слава - носилац славе; слава - социјум; слава - мишљење; слава - престиж; слава - рат; слава - православље; слава - гордост; слава - лош глас итд., које ауторка идентификује у руској лингво- 
култури изостаје парадигма слава - крсна слава, што указује на денотативну нееквивалентност, односно непостојање дате реалије (крсне славе) у руској култури (Кончаревић, 2006, стр. 140-141). Коje ће из мноштва парадигми представљати језгро концепта, а које његова периферијска значења, при анализи писане грађе, умногоме ће зависити од природе и тематске ширине те грађе. ${ }^{3}$ Отуд не изненађује што у материјалу ексцерпираном за ову прилику, предњачи херојска, ратна слава и она која подједнако припада појединцу и одређеном (српском) народу, и то како у представи српских, тако и словеначких, италијанских, француских и др. аутора. Важнија од тог податка јесте садржајна природа тог концепта, тј. идејна „композиција“ те прототипичне - ратне славе.

Прво што се запажа јесте да се слава српских војника у Великом рату ослања на „прошлу славу“: у йрошлу славу іopga сриза скрисмо (Божидар Пурић, „Ратници“), односно „минулу славу“: Бојић је волео gане наше минуле славе [...], каgа се у љубави умирало и за

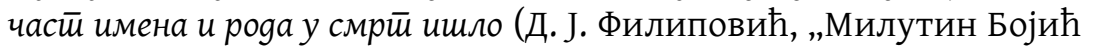
1892-1917), „стару славу“: Леіеняа јеgна можgа већ се сйвара, / Оіром-

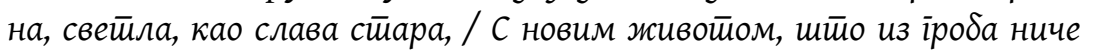
(С. Вешевић, „После помена на Виду“). Под наведеним синтагмама има се на уму у првом реду слава Косова које је трасирало пут и предодредило карактер сваке будуће, тј. „нове славе“, јер: Jegном, на Косову сйари славно йаше - пева Милош Н. Ђорић, а Нико

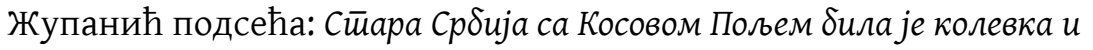
іроб срйске славе и величине у среgњем веку („Косово“). Зашто је то присећање потребно? Зато што је, како каже Алаида Асман, „сећање спасоносно, јер оно гради мост између знаменитих времена прошлости и будућности преко мрачне садашњости“ (1999, стр. 133). Писци у годинама Великог рата у косовској погибији, дакле, виде не само тематски ослонац већ и духовни оријентир који имплицира физичку смрт и спас у Царству небеском. Јунаци, по правилу, славно йagajy настављајући да живе. То је ठезмало опште уверење оних који сведоче о ратним догађајима. Тако

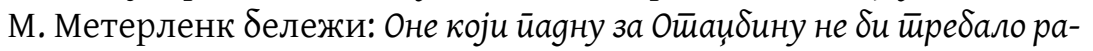

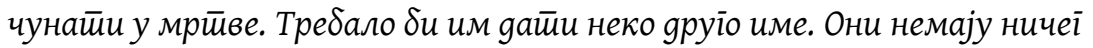
зајеgничкої са онима, који у својој ӣосӣељи заврше јеgан исӣрошен жи-

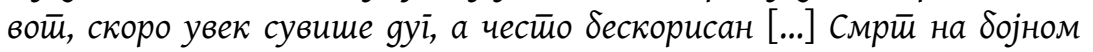

„Језички стереотип може се реконструисати на основу три типа података: системских (лексичко-граматичких добијених из речничких извора), конвенционалних (из анкетних истраживања) и текстуалних (из различитих функционалних стилова)“ (Ристић, 2013, стр. 256). 


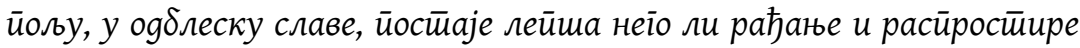

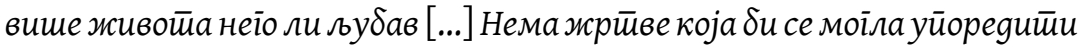
са оном коју су они gали; и збоі йоїа нема славе, која би се моіла узвиси-

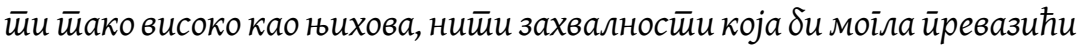
ову, коју им ми gуіујемо („Одломци рата“, с франц. превео Ж. М. Р.). Иста мисао заокупља и Растка Петровића који унапред види венце Проивале с нова изнаg мрӣвих ілава и преживеле који ће по повратку кући неумитно „подлећи у животу“, јер: Карика ви стие cag

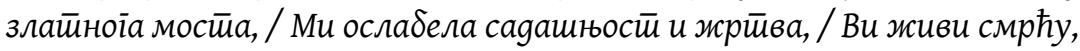

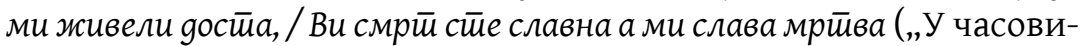
ма сумње“). Да је слава у Великом рату, таман као и слава косовских јунака, како би рекао Ј. Лотман, „индиферентна на резултате“, потврђују и Србији посвећени стихови Тина Ујевића: суйра, сабирући и gанас и јуче, / засјаћеш у gуху и у живој моћи. / Јер ће славу слома унуизи gа уче / као зору сйаса иза ӣешке ноћи.

Страдање, патња - физичка и душевна, тј. свесно жртвовање за спас и славу Отаџбине неизбежна је претпоставка војничке славе представљене на страницама новина и часописа штампаних током Великог рата. Ко је виgео наше љуgе како ћуйке, без іунђања, ठез

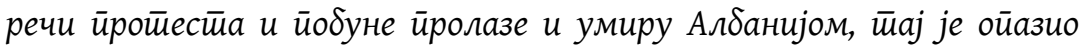

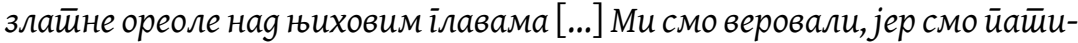

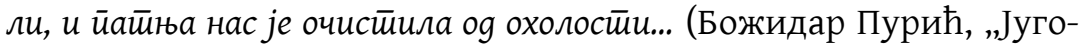
словенска истина“). Патња, дакле, прочишћује, просветљује и посвећује, нашта указују златни ореоли над главама оних који пролазе албанску голготу и чије се страдање не једном пореди са страдањем Христовим. ${ }^{4}$ Злайни ореол је синоним за ореол славе; две синтагме често и наизменично користе аутори периода о којем говоримо. Ореол славе директно повезује славу са светлошћу и са светошћу. Та веза се очитује и у низу стихованих примера. Шӣаје наша наgа, наша воља? - пита се Тодор Манојловић и одмах

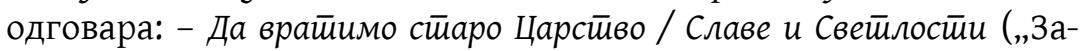
вет“). Почетни верзал у последњим двема речима јасно показује да оне нису употребљене у њиховом профаном значењу. Слава је сама по себи светлост. Она зрачи и сија попут радијума, како каже С. Винавер, пламти као у песми „Косовка“ Растка Петровића

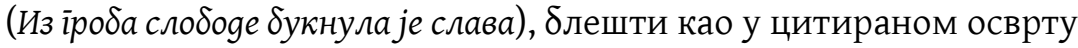
М. Метерленка. Светлост је у сакралном дискурсу ништа друго до живот који након физичког одласка задобијају само посвећени,

4 „Још нисам знао да су патнички Исус и озарени Исус једно“ - каже Бела Хамваш (1991, стр. 163), па наставља: „Озарен може ठити само онај ко пати. То је смисао блиставог крста“. 
чија се слава, како каже песник, у зений ӣойела те оданде опомиње и соколи нове нараштаје: Јер с наших ноћи и блисйавих звезgа, / Јер с наших gана и млаgих сунаиа, / Јер с наших зрачних и срушених інезgа, / Небо ће њима сјај славе gа байа (Растко Петровић, „Нове звезде“). Поред прототипичног значења војничке славе као златног (сјајног) ореола или зеленог венца (Око іробнице косовских јунака нароgни райсоgи сйлели су вечийо зелен венаи славе - Н. Жупанић, „Трагедија и нада Југословена, поводом Видов-Дана 1918. у Енглеској“), што у оба случаја симболизује живот а што се у терминима концептуалних или појмовних метафора ${ }^{5}$ може предстаВИТИ Као СЛАВА ЈЕ СВЕТЛО, СЛАВА ЈЕ ЗЕЛЕНО, СЛАВА ЈЕ (И најдосЛОВНИје) живот (... gошао је моменай gа се више не може назаg, већ или у славу или у смрй - Тадија Пејовић, „Батаљон 1300 каплара“). У смислу оријентације (оријентационе метафоре), у највећем броју примера, слАВА ЈЕ Високо, она се у зений йење, уздиже и вијори (Прейороg

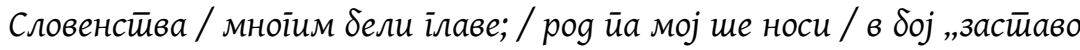
Славе“ - Фран Радишчек, „Оживљене наде“), дакле, супралокална у односу на свеколики земни живот (Perak, 2011, стр. 258), као што је НАПРЕД, никада назад (Зайо найреg у славу за ойайбину и за Беоїраg - командује Драгутин Гавриловић). Надаље, слАВА ЈЕ ПутовАњЕ,

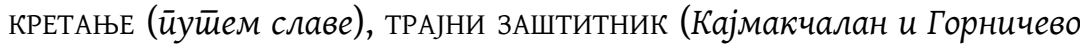
који йокрише славом војнике војвоgе Мишића и ђенерала Васића... Влад. Р. Петковић, „Српска црква после Косова“), гдекад и садржАЈ коЈИ ИСПУњАВА ВРЕМЕ: Жан Дорнис поводом смрти Милутина Бојића каже, између осталог, како је српска исйорија била йуна славе. Коначно, слАВА ЈЕ поБожност, посебно испољена у поштовању мајке. Осврћући се на ликове мајки, саздане у камену или на платну, а поводом смрти Риста Вукановића А. Арнаутовић наглашава: И оне су наша национална слава. И слава је йолико већа шйо ठожанске врлине живе у йим женама [...] Ми синови њихови, са смерном йобожношћу, заіллеgамо йе лейоие унуйрашње, gискрейне и ненаямашне величине. Ийо наше ӣобожнно йошйовање нова је наша нациионална слава („На гробу националистичког сликара“).

5 Термин йојмовна или концеййуална мейафора први пут се појављује у студији Џ. Лејкофа и М. Џонсона (Lakoff \& Johnson, 1980) у којој се проблем метафоре сагледава из перспективе когнитивне лингвистике и утврђује да метафора није тек језичка фигура за којом радо посежу писци, већ да је она саставни део нашег појмовног система, што нам омогућава да апстрактне појмове разумевамо уз помоћ конкретних којима обилује људско искуство. Појмовне метафоре аутори су класификовали на структурне, онтолошке и оријентационе. 
На другом месту по учесталости јављања у песмама, приповестима, дневничким записима из Великог рата је крсна слава и годишњи црквени празник, у првом реду Божић. Управо крсно име и Божић искрсавају у сећању бораца у тренуцима осамљености или у предсмртном часу. То присећање по правилу оживљава слику далеког дома у којем централно место заузимају мајка, славска икона, свећа и славски колач. Неодвојивост мајке и крсне славе као највећих вредности породичног дома ондашње патријархалне српске културе већ су уочиле Стана Ристић и Ивана Лазић-Коњик при анализи Шантићеве песме „Моја соба“, а у контексту концептуализације gома у српском језику (2012). Ту слику најбоље илуструју следећи стихови из Великог рата: Cagje Божић йамо!... Знам, мајка је сйара, / Блеgа као јесен, уйалила сйрасно / Слав-

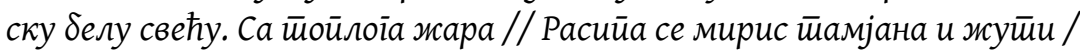

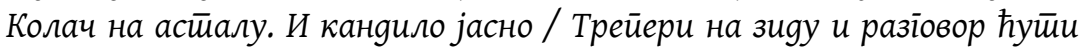
(А. Франичевић, „Под ведрим небом“). Чезнући за топлином дома, ратник неретко себе замишља како ненадано стиже на славску свечаност и доноси својим родитељима неописиву радост: Сањам срећне gане сииарої самосйана: / суморан, са слуйњом сйиїао сам gома. / Сусеgи и сроgна званииза је звана. / Мајка саморана и ойаи

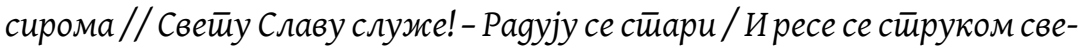

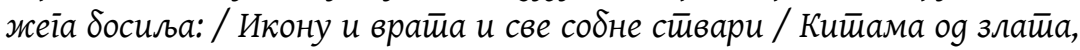
смиља и ковиља! // И зgравииу свима! И у йоме часу / Сйару славску слику обасу веgрина, / Сунчево се снойље свуg йо сйолу расу: / Сайайниизи стиари саїлеgаше сина!... (С. Миленовић, „Слава“). У сликама које нам доносе приповести из Великог рата пламен славске свеће неретко се меша са пламеном самртне воштанице хероја на из-

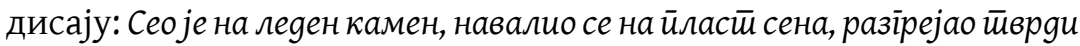

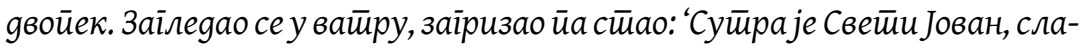

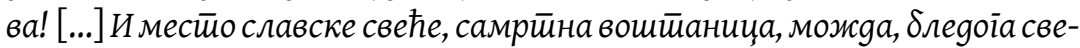
иза іреје!' [...] Дошао је gо ӣраїа и чује йойли жамор на веселоме gому.

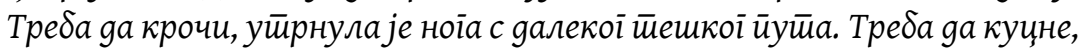
укочила се рука с йушчаном леgеном цзеви. Треба gа каже, занемео је је-

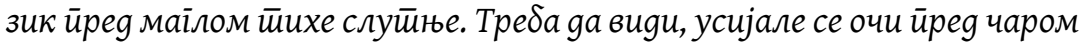
блиске среће. Треба gа кликне, заиірало је срие йреg славом и йреg Славом!! 0, зар gа клоне, никаgа клонуо није... (С. Миленовић, „Две ледене сузе“). И у записима превасходно документарног карактера, божићна атмосфера далеко од завичаја послужи хроничару да нагласи како смрт након надљудских патњи нужно доноси спасење - славу новог живота. Док, на пример, неименовани шеснаестогодишњи дечак добровољац у Каваји 1915. у свом дневнику дети- 
ње искрено тек констатује „Тужан је и Божић“, Јосип Јерас сведочи: У йристианишӣу Сан Бовани gочекали смо Божић 1915 [...] Умеђуна-

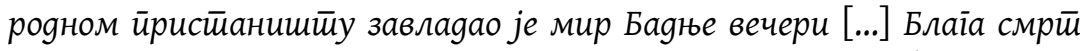
сйизала је нечујно og јеgної gо gруїої и gелила сйасење... („Планина смрти“). Са таквим и оправданим уверењем да после толиких патњи мора доћи спасење, ратници се обраћају Творцу (Слава Божија ${ }^{6}$ је на трећем месту по учесталости јављања) са једином жељом да надвладају те патње и не поклекну пред искушењима

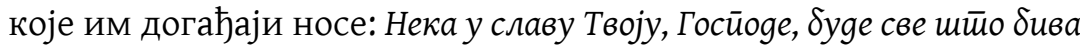
йо вољи Твојој и нека йайње никаg не gосеїну снаїе наше... (Жив. Девечерски, „На сестрином гробу“).

С обзиром на данашње свеприсутно, медијско и свако друго, промовисање прагматизма, очекивали бисмо да у језичкој слици света савремених корисника српског језика, барем оних који се држе подаље од Цркве, материјални аспект славе оличен у новцу, моћи и популарности, заузме водеће место при концептуализацији датог појма. Резултат у скорије време спроведене анкете у којој је корисницима српског језика (ретким, као и редовним посетиоцима Цркве, свештеницима и будућим богословима) у својству стимулуса понуђено 15 општепознатих речи са различитим семантичким потенцијалом у сакралном и профаном дискурсу, међу којима је била и реч слава, таква очекивања није потврдио. Наиме, уз стимулус їopgocī са веома негативном концептуализацијом (примарно као грех и предрасуда), још само у случају стимулуса слава, испитаници који се декларишу као атеисти уочљиво су манифестовали, можда и мање свесну, везаност за православну традицију (в. Рељић, 2013, стр. 235-254). Ако се узме да

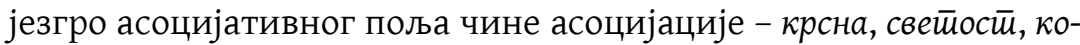

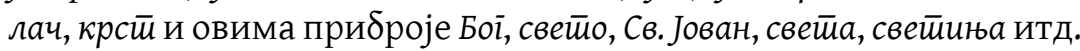
с периферије поља, видеће се да више од половине укупног броја асоцијација представљају речи из сакралног лексикона само код поменуте групе испитаника. Узму ли се у обзир одговори редовних посетилаца Цркве те свештеника и ученика богословије, таква концептуална структура појма слава постаје још изразитија.

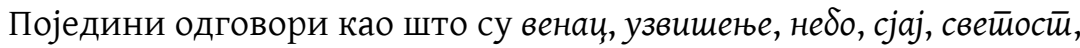

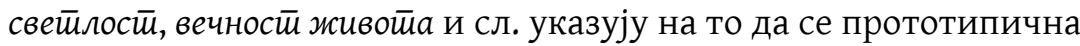

6 У оквиру српских средњовековних књижевних појмова слава се јавља и као

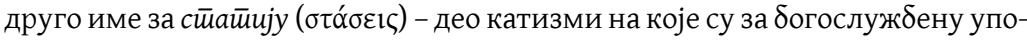
требу подељени псалми. „Сваку катизму чине три славе или три антифона, који се завршавају песмом:'Слава Оцу и Сину и светоме Духу'“ (Трифуновић 1990, стр. 293). 
представа славе у данашњој језичкој слици света скоро не разликује од оне коју нам нуди писана грађа из година Великог рата. У оба случаја слава се примарно везује за сакралну сферу. Пола века другачије животне праксе, по свему судећи, било је недовољно да избрише ту сакралну ауру славе. С друге стране, у речничкој одредници датог појма, упркос једном броју сакрално обојених примера, његова религијска маркираност остаје скривена. Разлог за то није тек у идеолошкој оријентацији састављача шестотомног Речника већ у језичкој слици света друштва као целине у време његовог настанка и, ништа мање, у тежини и деликатности посла лексикографа у свим временима.

ЛИТЕРАТУРА Винавер, С. (1971). Чувари свейа. Нови Сад - Београд: Матица српска Српска књижевна задруга.

Драгићевић, Р. (2010). Вербалне асоиијащиије кроз срӣски језик и кулӣуру. Београд: Друштво за српски језик и књижевност Србије.

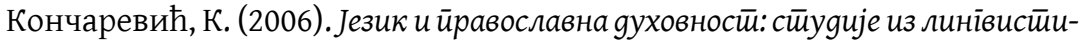
ке и йеолоіије језика. Крагујевац: Каленић.

Лазаревић, В. (2001). Срйски именослов. Земун-Нови Београд: Book-Marso.

Лома, А. 2002. Пракосово: словенски и йраиняоевройски корени. Београд: Балканолошки институт САНУ.

Лотман, Ю. М. (1992). Об оппозиции «честь» - «слава» в светских текстах киевского периода. В: Избранные статьи в 3-х т.т. Т. II. Талин.

Нагибина, Е. В. (2002). Концеетт «слава» в русском языке: Лингвокультурологический аспект. Доступно на: http:www.dslib.net/russkij-jazyk/conceptslava-v-russkom-jazyke-lingvokulturologicheskij-aspekt.html.

Пипер, П., Драгићевић, Р. и Стефановић, М. (2005). Асоиијайивни речник срӣскоїајезика. Београд: Службени лист СЦГ - Београдска књига.

Рељић, М. (2013). Асоцијативни искази у контексту „сапребивања у телу или у истом духу“ и њихов комуникацијски потенцијал. У: Теолинівисйичка йроучавањ а словенских језика = Theolinguistic Studies of Slavic Languages. Београд: САНУ - Одељење језика и књижевности (Српски језик у светлу савремених лингвистичких теорија, књига 5), 235-254.

Ристић, С. и Лазић-Коњик, И. (2012). Дом у срйском језику. Доступно на: http://www.rastko.rs/rastko/delo/14705.

Ристић, С. (2013). Концепт дома у религијском дискурсу. У: Теолинівисйичка йроучавањ а словенских језика = Theolinguistic Studies of Slavic Languages. Београд: САНУ - Одељење језика и књижевности (Српски језик у светлу савремених лингвистичких теорија, књига 5), 255-275. 
Трифуновић, Ђорђе. 1990. Азбучник срӣских среgњовековних књижевних йојмова. Београд: Нолит.

Фасмер, М. (1987). Этимологический словарь русского языка в четырех томах. Том 3. Перевод с немецкого и дополнения О. Н. Трубачева. Москва: «Прогресс».

Хамваш, Б. (1991). Тајни записник (С. Бабић, прев.). Писмо, 24, 142-197.

Asman, A. (1999). O metaforici sećanja (Aleksandra Bajazetov-Vučen, prev.). R.E.Č. Časopis za književnost $i$ kulturu, i društvena pitanja, br. 52, 121-135.

Lakoff, G. \& Johnson, M. (1980). Metaphors We Live By. Chicago: The University of Chicago Press.

Perak, B. (2011). Jezično opojmljivanje iskustva svetoga. Prinosi kognitivne lingvistike kognitivnim znanostima o religiji. Suvremena znanost $i$ vjera. Mostar, 241-272.

Ramšak, M. (2013). Posredovanje kulture u jeziku: utjecaj kulture časti na svakodnevni život. Narodna umjetnost: hrvatski časopis za etnologiju i folkloristiku, Vol. 50 No. 2, 7-32.

ИЗВОРИ

Ненин, Миливој (приређивач). 2005. Крфски забавник [фототипско издање]. Бања Лука - Београд: Бесједа.

Ђурић, Силвија и Видосав Стевановић (приређивачи). 1986. Голіотеи и ва-

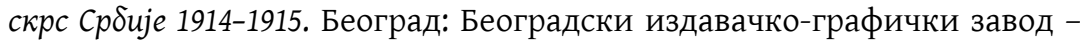
Партизанска књига.

Ђурић, Силвија и Видосав Стевановић (приређивачи). 1986. Голіот̄а ива-

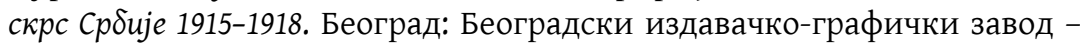
Партизанска књига.

Речник 1967-1976: Речник срӣскохрвайскої књижевної језика 1-6. Нови Сад - Загреб: Матица српска - Матица хрватска. 


\section{МИТРА М. РЕЛИЧ}

Университет в Приштине с временным пребыванием в Косовска-Митровице Философский факультет

РЕЗЮМЕ $\quad$ ПОНЯТИЕ СЛАВЫ В ЛИТЕРАТУРНОМ И ПУБЛИЦИСТИЧЕСКОМ ТВОРЧЕСТВЕ
ПЕРИОДА ПЕРВОЙ МИРОВОЙ ВОЙНЫ

Темой настоящей статьи является концептуальная структура понятия слава, выявившаяся на страницах литературных и публицистических произведений, созданных в годы Первой мировой войны. Воспользовавшись анализом упомянутых произведений (с опорой на лексикографические данные) как основным методическим приемом, нам удалось снова раскрыть, помимо общеславянских значений, и некоторые, лишь сербской культуре свойственные значения данного слова. Более того, анализ показал, что из ряда значений, зафиксированных в словарных статьях, для концепта славы в военные годы типичными являются: 1) почетная, неувядаемая воинская слава, 2) крестная слава, 3) Слава, восхваляющая Бога. Сравнивая данные результаты с результатами недавно проведенного нами опроса, весьма показательным оказывается то, что те же значения, только в измененном порядке, были прототипичными ассоциациями респондентов - как священников и верующих мирян, так и тех, которые почти никогда не ходят в Церковь.

КлючевыЕ Первая мировая война, слава, концепт, концептуальная метафословА: ра, языковое мировоззрение.

Овај чланак је објављен и дистрибуира се под лиценцом Creative Commons Ауторство-Некомерцијално Међународна 4.0 (СC BY-NC 4.0 |

https://creativecommons.org/licenses/by-nc/4.0/).

This paper is published and distributed under the terms and conditions of the Creative Commons Attribution-NonCommercial International 4.0 licence (CC BY-NC 4.0 | https://creativecommons.org/licenses/by-nc/4.0/). 